\title{
The lower crustal Dasu Tonalite and its implications for the formation- reformation-exhumation history of the Kohistan arc crust
}

\author{
Takashi Nakajima†*, IS Williams‡, H Hyodo§, K Miyazaki†, Y Konoף, AB Kausar\#, SR Khan\#and T Shirahase† \\ †Institute of Geoscience, Geol ogical Survey of Japan, AIST Central-7, 1-1-1 Higashi, Tsukuba, 305-8567, JAPAN \\ †Research School of Earth Sciences, Australian National University, Canberra, ACT 0200, AUSTRALIA \\ $\S$ Geochronological Laboratory, Okayama University of Science, Ridai-cho, Okayama 700-0005, JAPAN \\ II Graduate School of Environment and Information Sciences, Yokohama National University, Toki wadai, Yokohama, 240-8501, \\ JAPAN \\ \#Geoscience Laboratory, Geological Survey of Pakistan, Shazad Town, Islamabad, PAKISTAN \\ * To whom correspondence should be addressed. E-mail: tngeoch.nakajima@aist.go.jp
}

\section{Geological outline of the Kohistan block}

The Kohistan block in northern Pakistan represents an exposed crustal cross section to near-MOHO depths of an ancient island arc which becamesandwiched between the Eurasian and Indian continents. The Kohistan lower crust is composed of three geological units: south to north, ultramafic rocks and mafic granulites (Jijal Complex), banded amphibolite (Kamila Amphibolite) and a gabbronorite and ultramafic association (Chilas Complex). These units are geologically continuous, with no major tectonic breaks between them. The Kohistan block is tilted to the north due to uplift by subduction of the Indian continent from the south. Tonalite sheets intruding the lower crustal sequence of the Kohistan block provide key information on the dynamic history of the Kohistan arc crust.

Dasu Tonalite in the lower crustal sequence

Asilicic melt pod which first appears in garnet pyroxenite of the Jijal Complexdevelops into granitic rock in theoverlying Kamila Amphibolite. In the upper part of the Kamila Amphibolite it expands into kilometer-sized tonalite sheets, the Dasu Tonalite. TheDasu Tonaliteisa weakly foliated epidote-garnet-muscovitebiotite-hornblendetonalite. It wasemplaced as sheet-likebodies of varioussizes layer-parallel to thestructure of thehost banded amphibolite, suggesting syn-tectonic intrusion. Based on geothermobarometry on the amphibolite, the tonalite is estimated to have been intrtruded at 20-30 km depth (Yoshino et al. 1998), implying that it was generated and emplaced into thelower crust of theKohistan arc. This conclusion is consistent with the presence of magmatic epidotes in theDasu Tonalite, an indicator of high-pressurecrystallization.

\section{J uvenile granitic magma in the lower crust}

The Dasu Tonalite is extremely poor in $\mathrm{K}_{2} \mathrm{O}(0.6-0.9$ wt\% at $65-$ $70 \% \mathrm{SiO}_{2}$ ) and $\mathrm{Rb}(18-28 \mathrm{ppm})$, indicating that it contains no recycled upper crust. It is also depleted in $\mathrm{Zr}, \mathrm{Y}$, Th and $\mathrm{Nb}$ compared to common arc granitoids of similar $\mathrm{SiO}_{2}$ content, such as the Cretaceous Circum-Pacific granitoids. The initial ${ }^{87} \mathrm{Sr} /{ }^{86} \mathrm{Sr}$ ratio of the tonalite is low, $0.7037-0.7038$, similar to the lower crustal rocks of the Kohistan block and within therange of felsic rocks from the oceanic Izu-Bonin arc (Taylor and Nesbitt 1998). These features suggest that the Dasu Tonalite formed from juvenile granitic magma generated from mantle-derived lower crustal mafic components without interaction with the Indian craton, which presumably now tectonically underlies the Kohistan block.

\section{Geochronology and tectonic implications}

Two samples of Dasu Tonalitehavegiven aSHRIM P zircon U-Pb ageof $98 \mathrm{Ma}$. Theeuhedral shape of thezircon grainsand absence of overgrowth or resorption textures in cathodoluminescence indicate a simple magmatic history starting at $98 \mathrm{Ma}$, with no secondary thermal event. The ${ }^{40} \mathrm{Ar} /{ }^{39} \mathrm{Ar}$ biotiteage of thetonalite is $70 \mathrm{Ma}$. The $28 \mathrm{~m} . \mathrm{y}$. discrepancy between the two geochronometers is interpreted as a measure of the deep crustal residence time of the Dasu Tonalite. Tonalite magma generated and crystallized at $98 \mathrm{Ma}$ probably remained at lower crustal temperatures of about $700-800^{\circ} \mathrm{C}$ (as indicated by geothermometry on theintercalated Kamila amphibolite) before cooling to ca. 300 U C at $70 \mathrm{Ma}$, possibly when the Kohistan block was tilted, uplifted and exhumed due to the collision of India.

Dynamic processes in the Kohistan lower crust

Theisotopic ages reported on the Kamila amphiboliteand Chilas gabbro complex are remarkably scattered. Although this might be due in part to variation in the quality of the data, some of the scatter might also reflect a protracted emplacement and cooling history for theserocks. Along deep-crustal residencetimecould cause petrological reformation and isotopic re-equilibration after theigneouscrystallization of thegabbrosand conversion of those rocks to amphibolites. At least the upper half of the Kamila amphibolite consists of hydrated and recrystallized gabbro and gabbronorite equivalents of the Chilas complex (Yamamoto 1993). This interpretation is supported by the ubiquitous amphibolites in the Chilas complex. It would be reasonable to assume that the huge volume of the Chilas gabbro and gabbronorite was not produced in a single magmatic pulse, but formed by successive injections of mafic magma over a considerableperiod of time. This would have produced a mosaic of rocks frozen at various stages of the dynamic process from igneous crystallization to amphibolitization, which is what we now see.

\section{References}

Taylor RN and RW Nesbitt. 1998. Isotopic characteristics of subduction fluids in an intra-oceanic setting, Izu-Bonin Arc, Japan. Earth Plan Sci Lett 164: 79-98

Yamamoto H. 1993. Contrasting metamorphic P-T-time paths of the Kohistan granulites and tectonics of the western Himalayas.J Geol Soc London 150: 843-56

Yoshino T, H Yamamoto, T Okudaira and M Toriumi. 1998. Crustal thickening of the lower crust of the Kohistan arc (N. Pakistan) deduced from Al zoning in clinopyroxene and plagioclase. J Metamorph Geol 16: $729-48$ 